\title{
COMPLEXAS MEDIAÇÕES: transdisciplinaridade e incertezas nas recepções informacionais
}

\author{
COMPLEX MEDIATIONS: transdisciplinary and uncertainties in the \\ informational receptions
}

Luiz Tadeu Feitosa

UFC

\begin{abstract}
RESUMO
0 presente artigo analisa o conceito de mediação e suas interfaces informacionais a partir dos conceitos de complexidade e transdisciplinaridade, enfocando o caráter das incertezas que essas complexidades provocam na aferição dos fenômenos. Partindo dos elementos teóricos, conceituais e metodológicos presentes na ementa de uma disciplina de pós-graduação, intitulada "Cultura e Mediação da Informação", é discutido o caráter hermético das disciplinas, a pouca elucidação epistemológica do conceito de mediação no âmbito de alguns estudos da Ciência da Informação e da defesa de que apenas por um viés transdisciplinar é possível rever conceitos, alçar voos epistemológicos mais amplos e menos fechados e ensejar que ementas disciplinares se ocupem de visadas teóricas que contemplem os aspectos culturais aonde acontecem as mediações. As reflexões apontam para a necessidade de levar em conta as complexidades do conceito de mediação e de que o simples aparato organizacional e de oferta da informação não garante uma mediação de fato.
\end{abstract}

Palavras-chave: Mediação. Conceito. Ciência da Informação. Recepções informacionais.

\begin{abstract}
This article analyzes the concept of mediation and its informational interfaces from the concepts of complexity and transdisciplinarity, focusing on the character of the uncertainties that cause these complexities in assessing the phenomena. Based on the theoretical, conceptual and methodological elements present in the menu of a course graduate, entitled "Culture and Mediation Information", the hermetic nature of courses is discussed, little epistemological elucidation of the mediation concept under some studies of Information Science and the defense only for a transdisciplinary bias can review concepts, raise broader epistemological flights and less closed and give rise to disciplinary menus concerned with theoretical target that address the cultural aspects where happen mediations. The reflections point to the need to take into account the complexities of the concept of mediation and that the simple organizational apparatus and provision of information does not guarantee an actual mediation.
\end{abstract}

Keywords: Mediation. Concept. Information Science. informational receptions. 


\section{INTRODUÇão}

Ainda que os conceitos de mediação no âmbito da cultura e da comunicação já sejam preocupações nossas ao longo de vinte anos na condução de uma disciplina de graduação chamada "Cultura e Mídia", e venham ensejando aplicações teóricas, conceituais e metodológicas nos seminários temáticos que ela produz para dar vez e voz a convidados que se debruçam sobre fenômenos culturais e midiáticos, o presente artigo nasceu a partir de inquietações promovidas pela leitura da ementa da disciplina "Cultura e Mediação da Informação", que inaugura o mestrado acadêmico do Programa de Pós-Graduação em Ciência da Informação da Universidade Federal do Ceará (PPGCI/UFC).

Envolvendo não apenas várias formas e tipos de mediação, mas, sobretudo, uma complexa "teia de significações" (GEERTZ, 1989) envoltas nos processos culturais de mediação; e mais suas especificidades mediativas e não menos complexas no âmbito dos fenômenos informacionais, a disciplina em foco traz na ementa abaixo sinais explícitos de que apenas sob o jugo das teorias, conceitos e epistemologias transdisciplinares se pode dar conta das reflexões que ela sugere.

\footnotetext{
Abordagens teóricas relativas ao estudo da mediação cultural e informacional. Reflexões e análises sobre os processos infocomunicacionais e as mediações socioculturais da informação. Formas de mediação, recepção e apropriação da informação pelo usuário, bem como a sua ação crítica interpretativa e de ressignificação. As representações e os conteúdos simbólicos da cultura informacional na sociedade. (Ementa da disciplina "Cultura e Mediação da Informação" PPGCI/UFC 2016).
}

Como se percebe, a simples menção ao que se concebe chamar de "abordagens teóricas" nos leva a pensar num criterioso levantamento dos conceitos de mediação e suas visadas teóricas transdisciplinares. Assim, estudos sobre mediação cultural a partir do conceito antropológico de cultura (CAUNE, 2014; ELIAS, 1990; GEERTZ, 1989; LARAIA, 2008) são necessários para que possamos entender de que modo a mediação informacional se dá, analisando com firmeza as complexidades e as incertezas com que o fenômeno lida dentro das mediações informacionais.

Necessário se faz situar os processos informacionais nos contextos culturais e sofisticar o estudo desses fenômenos à luz de uma filosofia da complexidade, analisada com rigor por Morin (1996, 2007) e recuperada em análises sobre transdisciplinaridade (D’AMBRÓSIO, 1997; MORAES, 2015) e que subsidia este artigo de reflexões necessárias para pensar o tema 
da mediação proposto pela ementa em questão.

Assim, sob a preocupação de viés complexo, analisar o que são processos informacionais, como se caracterizam, que bases teóricas os sustentam e o que de fato produz ou sintetiza uma "ação de mediação informacional" deve estar nas preocupações da referida disciplina; as bases antropológicas dessa informação e dos contextos culturais onde elas se dão; estudos epistemológicos dos tipos de mediação; de mediação informacional; estudo dos processos comunicacionais: a diferença destes com os processos informacionais; o que são, suas características, suas bases teóricas; as epistemologias deste tipo de mediação (FERRARA, 2014; MARTIN-BARBERO, 2009) e as "mediações socioculturais da informação": o que seriam mediações socioculturais de fato. E o que seria isso sob o jugo ou atrelado à informação ou a processos de mediação informacional.

Isso nos leva a formar questionamentos sem necessariamente ter de responder às questões, uma vez que, o que move essas reflexões é o estudo das complexidades e o papel da transdisciplinaridade nos fenômenos culturais e informacionais de mediação. Nesse tocante, cabem algumas perguntas sobre os fenômenos apresentados na ementa em foco e que sublinham as intenções reflexivas da disciplina em lide.

Encerra-se a mediação "sociocultural da informação" a partir apenas da disseminação da informação nos moldes tradicionais do fazer bibliotecário? Como se daria essa mediação sociocultural da informação? Ela é factível, mensurável, observável ou é apenas um apelo discursivo? Por que a maioria dos artigos científicos sobre "mediação informacional" ou "mediação da informação" se restringe apenas a dizer da sua importância; a dar exemplos práticos de "mediação"; a focar essa mediação na prática de oferta de serviços bibliotecários; na prática apriorística de organização e tratamento da informação e quase nunca se define o que seria essa mediação informacional? Dentre os variados tipos de conceitos sobre mediação, quais os que se aproximam verdadeiramente do fazer mediador da Ciência da Informação? É possível medir essa mediação informacional, mediação sociocultural da informação, sem aferir a cultura e os contextos culturais para onde se dirigem a informação "mediada"? Nesse contexto, não caberia a reflexão de que o fazer da Ciência da Informação estaria mais voltado para a mediação cultural do que para o atendimento às demandas mais pragmáticas de oferta de informação?

Perguntas que este artigo não pretende responder, mas ensejar que as reflexões sobre esses assuntos se entreguem aos estudos da complexidade e às investigações transdisciplinares, objetivo deste artigo. Dessa forma, a presença da tríade "formas de mediação", "recepção da informação" e "apropriação da informação" contida na ementa da 
disciplina "Cultura e Mediação da Informação" já não extrapolaria o fazer pragmático tradicional da oferta de informação pela Ciência da Informação para abraçar uma preocupação com a cultura e suas complexas e incertas formas de mediação cultural?

Sim, porque preocupar-se com as formas de mediação, mesmo no específico contexto da mediação informacional, já deixa explícito que os aspectos ligados às diversidades culturais, aos diferentes contextos de produção, difusão, circulação e recepção de informações ensejam que as visadas da Ciência da Informação sobre essas possibilidades mediadoras sejam menos pragmáticas e passem a contemplar mais de perto as subjetividades dessas mediações e dessas ações de informação para as pessoas e seus diversos contextos culturais.

Quanto à "apropriação da informação", parece-nos que a aferição da mediação se apresenta um pouco mais complexa e de difícil tratamento empírico. Sugere-se, pois, que apenas a partir de uma mensuração dos contextos de mediação cultural onde essa informação recebida e apropriada se encontra; no contexto sociocultural com o qual interage; nos contextos e processos culturais onde essa apropriação informacional estabelece mecanismos e processo de "negociação" (MARTIN-BARBERO, 2009) é que se pode encontrar a mediação informacional.

Isto posto, chegamos a mais uma designação da ementa da disciplina em questão "ação de ressignificação" - para afirmar que a mediação da informação, a mediação informacional ou as "mediações socioculturais da informação" não podem ser aferidas sem antes a Ciência da Informação redefinir seu escopo teórico e conceitual sobre esse complexo conceito de mediação informacional. Isso levará o referido campo científico a reformular sua epistemologia da informação, no tocante a seus aspectos mediadores e também interativos. Há uma tendência cada vez mais explícita de que as formas de mediação informacionais complexas, plurais e incertas - proporcionadas pelo fazer da Ciência da Informação não podem se fossilizar na informação como matéria-prima, mas nas produções culturais, mediadoras e interacionistas que promovem, provocam e possibilitam no âmbito das "mediações culturais" (CANCLINI, 2003; CAUNE, 2014; MARTIN-BARBERO, 2009; THOMPSON, 1999).

Do mesmo modo, ao se falar de "cultura informacional" não se pode se limitar a quaisquer "culturas de uso" da informação, mas focar nas transformações que esta é capaz de proporcionar ao mundo e à cultura, mais do que apenas ao receptor imediato da informação ou da mediação informacional obtida. Essas perguntas seguidas das assertivas que sugerem respostas próprias da ementa, mas também da sua bibliografia básica, já ensejam que as 
reflexões apresentadas neste artigo sejam o ponto de partida para pensarmos as ementas das disciplinas mais do que em portos seguros disciplinares, mas em aspectos complexos que reclamam - como se verá a seguir - estudos e posturas transdisciplinares, porque uma ementa de disciplina não pode se render aos disciplinamentos herméticos de teorias e conceitos, mas ao experimento de voos mais livres, se quisermos dar conta das complexidades que existem para além da ementa e do título "Cultura e mediação da informação”.

\section{MEDIAÇÃO DA INFORMAÇÃO: entre complexidade e incertezas}

A cultura é o processo através do qual o homem cria o algo onde antes imperava o nada. Esse algo é toda complexidade de criações simbólicas, de sentidos e significados que damos às coisas e ao mundo. Um "algo" que não se sustenta se não se entender os processos culturais como mecanismos de mediação entre nós e os fenômenos. Assim, mais do que apenas um elemento da comunicação, a mediação é, por excelência, cultural. As diversas modalidades de mediação são apenas sotaques diferenciados dessa mediação cultural. Assim é a mediação informacional. Mas o que é ela? Por que o conceito é tão recorrente na Ciência da Informação e tão pouco refletido sob os auspícios da transdisciplinaridade que reclama sua elucidação?

Criticar o que se conhece para a "produção do novo que se pretende dar a conhecer" (FERRARA, 2015) implica não apenas revisitar paradigmas e epistemologias sobre a "mediação", mas pôr em curso um processo cognitivo que respeite os limites e as fronteiras de cada visada teórica e conceitual sobre o que é mediação, observando-se as porosidades do conceito e seus desdobramentos nos campos vários nos quais a mediação está. É essa espécie de convite que a ementa da disciplina "Cultura e Mediação da Informação" suscita na composição das reflexões que se espera de uma disciplina que se debruça sobre um tema/conceito tão diverso, tão complexo e tão plural.

Portanto, mesmo não sendo intenção deste artigo mostrar as fronteiras rígidas do que seja mediação no âmbito da Ciência da Informação, usamos a referida ementa para demonstrar que se faz necessário o mínimo de rigor no uso do conceito - para além do simples dizer como se pode fazer uma mediação - e proporcionar que outras visadas teóricas e conceituais sejam acrescidas ao processo cognitivo de definir mediação, principalmente usando as contribuições transdisciplinares que ajudam a compreender as complexidades e as incertezas do conceito e dos fenômenos que ele causa. 
Assim, antes de mais nada, é preciso que se diga que a simples sofisticação e responsabilidade dos sistemas de informação e disseminação da informação não garante uma mediação eficaz, se não se pensar na mediação da informação disseminada como proativa às reações positivas do usuário de informação. Não pode ser a supremacia do sistema de informação sobre a falta de reação do receptor/usuário. É nesse processo complexo de reação à informação recebida que se encontra a mediação. Não como produto acabado, mas como processo semiótico de construção de sentidos e de múltiplas facetas mediativas.

A mediação informacional não pode ser motivada apenas pelos suportes informacionais e nem pelos seus desdobramentos tecnológicos. Entre a linearidade da oferta e da procura informacionais deve estar a dimensão cultural da informação, seus processos de semiose informacional e as possibilidades de se aferir as chamadas mediações socioculturais. Não haverá processo de informação e nem mediação informacional se sobrepuserem os suportes e seu glamour tecnológico às mediações em devir interacionista.

Assim, não apenas as hegemonias dos suportes informacionais e seus sistemas sofisticados de armazenamento e de busca, mas também os condicionantes enunciativos e culturais do emissor - unidades de informação, bibliotecas, centros de documentação - devem ser revistos. Mais do que definir e determinar as fronteiras da emissão e da recepção, faz-se necessário se pensar nas suas interfaces, na porosidade das suas fronteiras e nos contextos culturais da informação, segundo seus processos de emissão, difusão, circulação e recepção. É na complexidade desse caminho e nos desdobramentos semióticos da informação nos contextos culturais que a verdadeira mediação se dá.

Apresentada quase sempre como ato ou efeito de potencializar e objetivar a disseminação e a transferência da informação, aliada ao próprio fazer do bibliotecário, a expressão "mediação da informação" acaba por transitar pelas ações pragmáticas de um fazer que une produtor/disseminador de informação com as demandas por informações. Sob os auspícios dessa lógica linear e, muitas vezes unilateral, a ação recíproca do ofertar e do receber negligencia as complexidades que uma informação propicia quando e depois de ser apropriada e, para além dessa apropriação, dos fenômenos díspares e incertos que fluxos informacionais causam na vida das pessoas.

Portanto, a chamada mediação da informação carece de esclarecimentos epistemológicos, sem que caiamos no perigo de aprisionar o conceito no âmbito da informação, como se mediação não fosse ela mesma um fenômeno gregário da cultura. Mediação que agrega, que proporciona trocas, que desagrega, que desterritorializa o próprio 
conceito, tornando-o incerto. No âmbito da Ciência da Informação, encontramos em Almeida Júnior (2009) uma preocupação com essas questões, e suas pesquisas se debruçam com entusiasmo sobre o tema.

\begin{abstract}
Numa conceituação implícita, proveniente da intuição, na concepção da maioria dos que escrevem e estudam o tema, a mediação da informação passa a fazer parte do discurso dos profissionais da informação, mas sem que embase suas práticas. Ao contrário: estas são dissociadas da teoria, uma vez que não está ela, teoria, articulada, organizada, sistematizada e explicitada. (ALMEIDA JÚNIOR, 2009, p. 91-92).
\end{abstract}

Vista como uma ponte pragmática que liga dois pontos - muitas vezes sem unir -, o conceito se esvazia de sentido quando não se observa as complexidades epistemológicas que se debruçam sobre ele: desde as mediações culturais até suas variáveis interacionistas em vários campos do saber. Assim, mediação também muitas vezes se confunde com interação, que dela se difere pelo alto grau de complexidade presente nas mais variadas formas de mecanismos gregários, civilizatórios e de ordenações socioculturais que interferem em nossas vidas. Assim, é que o autor supracitado achou limitada a síntese que sua pesquisa mostrava em 2009 sobre o que seria mediação no âmbito das preocupações da Ciência da Informação. A mediação como sendo:

[...] toda ação de interferência - realizada pelo profissional da informação -, direta ou indireta; consciente ou inconsciente; singular ou plural; individual ou coletiva; que propicia a apropriação de informação que satisfaça, plena ou parcialmente, uma necessidade informacional. (ALMEIDA JÚNIOR, 2009, p. 92).

Ainda que na referida pesquisa, a síntese acima venha ganhando outras visadas conceituais e epistemológicas mais complexas, mais amplas e voltadas para outras facetas de mediações socioculturais, históricas, identitárias, entre outras, parece que no imaginário dos bibliotecários a ideia de ponte que liga, mas não une, não está sendo levada em conta.

Mesmo sendo determinante dizer que "o armazenamento de informações" e as maneiras "implícitas" e "explícitas" presentes num fazer potencializem uma mediação informacional; ainda que se possa inferir que há muitas possibilidades de recepção dessas informações pelo usuário, o foco da "mediação" à luz dessa pragmática organizar/disseminar ou de produzir/receber se desfaz quando o conceito de mediação é movido para a sua complexidade e quando se nos apresentam de difícil aferição as incertezas de seus resultados subjetivos e mesmo os objetivados pragmaticamente. Nesse sentido, apenas um olhar mais transdisciplinar poderá ensejar que a mediação extrapole o que pode mediar, a importância e tipos de mediação para se aferir de fato o que seja mediar. 
A ação voltada para as necessidades do usuário - premissa básica de todo serviço de informação - não garante a mediação em sua inteireza, porquanto estabelece a lógica mediativa na relação unilateral emissor/produtor de informação para receptor/usuário de informação, numa lógica de que a comunicação se dá nos moldes de um processo que liga dois pontos ou que estabelece pontes entre duas demandas: a de informar e a de receber informação num sistema direto de informação.

No entanto, há outras lógicas de relacionamento entre demandas informacionais por informações em fluxos e em modalidades sistêmicas que extrapolam esse dar/receber dos sistemas tradicionais de bibliotecas, por exemplo. A emergência de serviços online e em bases de dados presentes em portais de periódicos, por exemplo, requer outras práticas mediativas, que se ocupem também da complexidade dessas buscas, da simultaneidade de buscas e respostas, dos desdobramentos instantâneos de buscas; ao invés das ofertas tradicionais, reclamam outras posturas mediadoras, como avaliar periodicamente os efeitos das informações recebidas e as "reações" a elas nos contextos socioculturais.

É preciso realçar que mediação e interação não são sinônimos. Estabelecida como ponte ou intercâmbios entre um emissor/acervo armazenado e um receptor/usuário, a mediação se apresenta unilateral. Numa prática de ação cultural em bibliotecas, mais do que ligar, possibilitar uma "ponte", o que se estabelece é uma troca, uma simbiose perceptual e cognitiva; o que prevalece é uma interação e uma "semiose" em movimento. Há mais do que trocas instantâneas de informações. Estabelecem-se múltiplas produções sígnicas, infocomunicacionais e semióticas; construções de sentidos que - ainda que inapreensíveis, porque fugazes e efêmeros - são produções de informação e de conhecimentos recíprocos.

\section{TRANSDISCIPLINARIDADE: para sair da clausura}

Sobre a discussão sempre presente na literatura científica acerca da transdisciplinaridade, uma nos chamou atenção. 0 matemático e pesquisador brasileiro Ubiratan D’Ambrósio saiu do campo fechado das Ciências da Matemática, onde sempre se achou envolvido, e, ao transitar por outros campos e outros cantos, enxergou com outros olhos o que Edgar Morin já vinha chamando a atenção há algum tempo: o caráter complexo dos fenômenos todos e o papel da transdisciplinaridade para melhor compreender as incertezas do mundo e dos seus processos de investigação científica.

Entre tantas outras formulações epistemológicas do que se considera complexo na 
Natureza, nos seus fenômenos e, sobretudo, nas buscas científicas, Morin sintetiza o conceito afirmando que "o complexo significa aquilo que é tecido em conjunto" (MORIN, 1990, p. 20), daí a incerteza presente nessa perspectiva de vários olhares serem necessários para aferir sistemas que não são simples. Isso exige do "observador científico" uma imersão no fenômeno observado sem que este se arvore do direito de investigar sozinho.

Com o olhar de um menino curioso e o mergulho profundo no viver dos cotidianos complexos, diversos e plurais de que são constituídos os cotidianos (CERTEAU, 1994), D’Ambrósio formulou a metáfora das "gaiolas epistemológicas", que sintetiza a dura contradição de as epistemologias criarem portos seguros nos quais e a partir dos quais formulam caminhos teóricos, conceituais e epistemológicos para as descobertas científicas, ao mesmo tempo em que essas epistemologias podem funcionar como prisões ou calabouços incomunicáveis a outras possibilidades investigativas e ao mergulho nesse mundo complexo e incerto. 0 mesmo vale para as ementas de disciplinas, ponto de partida dessas reflexões.

O pensar disciplinar, resultado do método proposto por Descartes, progrediu até surgir uma incrível capacidade de penetrar profundamente em seus estreitos campos de reflexão. Mas, à medida que se manifesta esse progresso, vai se perdendo a capacidade de uma visão ampla e global. Vai se deixando de reconhecer as interações entre os vários fatores que agem num fenômeno. A visão do holos torna-se difícil, senão impossível. (D’AMBRÓSIO, 1997, p. 77).

Inspirada na obra de Edgar Morin sobre a filosofia da complexidade e as incertezas científicas decorrentes disso, a metáfora das "gaiolas epistemológicas" sugere, como o pensador francês, que "o objeto do conhecimento não pode cair prisioneiro de uma disciplina especializada ou de uma área enclausurada do saber, uma vez que tudo é complexo" (MARTINAZZO, 2004, p. 21).

Ainda que aparentemente segura, como a "Casa de Salomão" ou a "Torre de Marfim", de onde vieram as ideias inspiradoras para a criação metafórica das "gaiolas epistemológicas", D’Ambrósio (1997) se refere a isso como um falso porto seguro, porquanto se exclui muito da realidade quando se opta cega e cartesianamente por escolhas que só se sustentam no interior desses espaços herméticos.

Gaiolas que aprisionam, que limitam contatos, que freiam cognições e movimentos perceptivos. Todo e qualquer pensamento preso e incomunicável no interior desses guetos de pensamentos o tornam empobrecidos pelo ar rarefeito e viciado que ali circula. Os pensamentos precisam unir, interagir-se com outros. Não pode o pensamento isolar ou separar outros pensamentos. Isso é relevante para ampliarmos os conceitos de "mediação" de que vimos falando neste artigo. 0 conceito de mediação, no singular, é sempre plural, e essa 
pluralidade encerra incertezas sobre as complexidades das ações, atos e fenômenos do mediar. Na Ciência da Informação estudos vêm tentando esclarecer melhor o que seria de fato uma mediação da informação.

0 conhecimento tradicional acaba nos levando às gaiolas. Romper com isso também não significa entrar e sair ou apenas deixar suas portas abertas para voos esporádicos. Se a gaiola é a disciplina de que nos fala D’Ambrósio, não é a sua ampliação que nos dará a transdisciplinaridade, posto que apenas teríamos transformado a gaiola num viveiro. Sair do conforto dessas gaiolas abertas ou possibilitar um condomínio teórico disciplinar diverso, onde alguns também presos podem conviver entre si, não garante a transdisciplinaridade. 0 conhecimento precisa da liberdade, precisa ser e estar solto. Alçar voos para além das "torres de marfim" ou de outras clausuras ventilará, oxigenará os conhecimentos e, consequentemente, seus conceitos e teorias podem se integrar, podem mediar uns aos outros. Isso também vale para o conceito de mediação e, mais especificamente, para o de "mediação da informação", conforme apresentado pela ementa em questão. $\mathrm{Na}$ mesma trilha investigativa, Maria Cândida Moraes pontua:

Assim, para se construir um conhecimento transdisciplinar, capaz de transcender as fronteiras disciplinares, é preciso trabalhar com base nesta outra lógica, já não mais dualista no sentido de transcender o nível de realidade primordial, para que o conhecimento possa emergir em outro nível, dialogando com as contradições e ambivalências. (MORAES, 2015, p. 44).

Transcender fronteiras e dialogar com contradições e ambivalências estabelece uma conexão com a reflexão sobre as gaiolas, ensinadas pelo pesquisador matemático, para quem nenhuma unidade curricular, nenhuma disciplina, nenhum cientista ou acadêmico pode ficar integralmente dedicado a uma sem correr o risco de se engaiolar ou de prender ciências como se prendem e se engaiolam pássaros. É preciso sair da zona de conforto e se livrar dos álibis de que os organismos científicos nacionais e os mecanismos de investimentos internacionais exigem e determinam essas clausuras epistemológicas. Para D’Ambrósio (1997), livrar-se das gaiolas também requer humildade, porque estar nelas muitas vezes significa obter benefícios. No entanto, permanecer nelas prejudica e ameaça, sobremaneira, a transdisciplinaridade.

Assim, voltando às reflexões sobre a ementa da disciplina curricular relacionadas à "cultura e mediação", bem como a respeito das várias facetas culturais e mediadoras num processo de investigação fenomenológica de uma informação cada vez mais complexa, dinâmica, diversa e incerta, temos de nos voltar também para o que Paulo Freire (2011) chamava de "ditadura dos conteúdos" e do mal que isso faz aos estudos, às investigações Inf. Pauta, Fortaleza, CE, v. 1, n. 1, jan./jun. 2016 
científicas e aos conteúdos disciplinares de estudos, inclusive os pós-graduados.

Se disciplina é o conhecimento engaiolado, inacessível ao outro, não podemos pensar em "interdisciplinas” como a simples "justaposição de gaiolas disciplinares" (D’AMBRÓSIO, 1997). É aí que entra a ênfase maior que deve ter uma mediação ou processos mediativos. Pensar numa transdisciplinaridade implica o fortalecimento das vias e entrecruzamentos conceituais, teóricos, comunicacionais e informacionais entre as ciências e entre seus pesquisadores, de quem se espera coragem, humildade e empoderamento em voos menos disciplinados. Isso implica sair do conhecimento disciplinar e focar no humano, nas ações humanas, nas suas formas de vida; na construção e ressignificação de seus cotidianos.

É necessário focar no humano e nas suas particularidades individuais; suas inclinações identitárias; seu papel na construção de sua cultura, identidade, memória e tradição. Mas o foco da ciência e do seu viés investigativo transdisciplinar deve também se voltar para o lado social do indivíduo; sua vida em cultura; os modos necessários para ele garantir sua sobrevivência. É preciso pensar mais na transcendência do humano do que na permanência das "epistemologias engaioladas". Isso é mediação. Mediação é esse voo comunicativo em interação, em compartilhamentos; mediar é garantir a liberdade e o exercício de um pensar junto, unido, integrado ao humano e às suas necessidades ditas e reivindicadas por ele e suas demandas, e não pelas ordenações socioculturais, sempre impositivas. Uma mediação em harmonia com o outro, com sua humanidade e transcendência, mesmo dando voz e vez às “contradições e ambivalências" da transdisciplinaridade, como sentenciou Moraes (2015).

Voltando à reflexão sobre o papel que cabe à ciência e às disciplinas que se arvoram como suas vozes muitas vezes unívocas, é preciso usá-las em fazeres pós-graduados como meios possíveis de abrirmos as gaiolas, sem a mantermos abertas apenas como garantias de que voltemos a elas. A metáfora de um mundo que reclama mediações e interações sem fronteiras rígidas também cabe nessas reflexões. Uma mediação informacional é aquela que foca muito mais nas necessidades de transcendência de usuários humanos do que na contrapartida unívoca de serviços de informação devidamente capacitados a provocar mediações, ainda que este conceito seja tantas vezes mal compreendido.

\section{INFORMAÇÃO: entre mediação e interação}

0 que é próprio da mediação e da interação parece estar mais na confluência fenomenológica dos dois conceitos, nas frestas entre eles, nas porosidades de suas fronteiras do que preso epistemologicamente num conceito ou no outro. Isso é relevante, porque para se 
falar de informação e cultura implica se ocupar da própria definição de fronteira como sendo uma espécie de espaço semiósico (PEIRCE, 1980), onde os significados mudam, se intercambiam; onde os sentidos se modificam e onde qualquer cultura no singular, será sempre plural.

Assim, cultura é o espaço ambivalente das linguagens em atualizações constantes de seus significados e do próprio caráter fenomenológico da informação produzida, difundida e recebida, sempre a criar novas semioses. Mudanças que se dão não apenas sob a égide dos seus sistemas de emissão ou sob os efeitos pragmáticos de suas recepções, mas, sobretudo, à luz dos fenômenos e devires que essa informação, seus fluxos e a profusão de sentidos culturais - mais do que meramente informacionais - promovem e provocam.

É, pois, na interface da mediação e da interação que é possível prever o valor cultural do fenômeno informacional, como processo dialógico entre uma demanda reprimida e sempre renovável e a aquisição informacional pragmaticamente recebida e já em trânsito para sua negação ou necessidade de atualização.

Ainda que não seja possível provar com maior precisão, é mais provável que as interações são mais importantes para a cultura (FERRARA, 2015, p. 14). Isso porque as interações se desdobram para além das relações de mediações mecânicas entre emissor e receptor; entre códigos de representação da informação e seus conteúdos; entre estes e os meios tecnológicos ou digitais que servem para o armazenamento e a recuperação da informação.

Isso é relevante para esclarecer o que pode embotar a expressão "cultura informacional" quanto a ela ser a cultura do uso em detrimento da cultura do desdobramento desse uso. A informação recebida - bem ou mal - não a torna menos refém do poderio enunciativo e cultural de quem a emite e da sua "materialização", como defende Frohmann (2008). Esse posicionamento mediativo, com ênfase na relação intrínseca emissor/receptor, e mais no poderio informacional e simbólico das instituições detentoras da informação, parece impedir uma aferição mais eficaz sobre a função sociocultural da informação. No caso, mais facilmente previsível de ser entendida à luz das interações - ainda que de difícil aferição científica - do que da mediação, que subtrai os efeitos culturais da informação para legitimar a relação hegemônica do emissor/receptor, um caminho de mão única e sem se levar em conta os desdobramentos culturais de uma informação nos cotidianos, construindo e destituindo deles os seus sentidos, numa semiose ilimitada. 
Semiose que também se dá para além dessa mediação linear. Assim, é preciso compreender o fenômeno atual da informação e comunicação em constantes trocas e compartilhamentos, "que nos faz aderir à própria lógica e transforma a comunicação em elemento cultural definidor da atualidade" (FERRARA, 2015, p. 16).

Numa referência quase explícita à lógica das comunicações de massa, muitos dos escritos sobre mediação informacional no âmbito da Ciência da Informação partem do pressuposto de que a grandiloquência dos sistemas de informação, de seus respectivos processos de armazenamento e recuperação da informação, garantem uma mediação informacional. O próprio conceito de "competência informacional” e seus desdobramentos práticos dão mais visão aos predicativos que se exigem contemporaneamente dos "cientistas da informação" do que da aferição desse uso cultural da informação, nos mais variados, complexos e incertos contextos de interação. Sabendo-se que a lógica do mundo da informação não se reduz à lógica do emissor/código/receptor, mas ao compartilhamento de informações, estudados por muitas novas teorias da mediação e, sobretudo, da interação e seus fenômenos de trocas, Ferrara (2015, p. 16) contribui com a seguinte reflexão:

Na verdade e em nossa leitura, a dinâmica desses estudos se adensa quando superam a lógica da cultura de massa que insiste em não reconhecer o receptor a quem se dirige e as dimensões de complexos processos interativos que, disseminados ambientalmente, tornam imprecisos os alicerces planejados e praticados pela comunicação de massa.

Nesse sentido, tanto a dimensão sociocultural da informação quanto a competência da informação não podem ser pensadas sob a lógica do dar/receber, do armazenar/recuperar, mas à luz das possibilidades do interacionismo cultural da informação e os efeitos dos desdobramentos dos seus usos no contexto das culturas e seus cotidianos.

A "mediação programada" pelos sistemas competentes de informação e suas respectivas "competências informacionais" pode parecer desinteressante ao usuário contemporâneo de informações, que já exercita o seu uso compartilhado e interativo, bem como experimenta o resultado dos diversos fluxos informacionais, com suas complexas redes de interação, suas diversas "teias de significação" e processos de mediação que se estabelecem mesmo é na interface do entre receber e usar a informação e os ganhos a partir dos usos. A mediação, então, ganha os contornos da interação por se dar nesse espaço entre receber e se apropriar da informação para uma mudança sociocultural.

Assim, a mediação pode ser programada, o que a torna previsível, e os seus efeitos serem lineares por serem pautados pela direção de mão única, do emissor para o receptor. Contrariamente, ainda que circunscrita às mesmas espacialidades informacionais, a interação 
figura "como uma possibilidade, um prognóstico comunicativo de complexas e inusitadas dimensões culturais que fazem envelhecer os antigos temas que nutriam os estudos culturais." (FERRARA, 2015, p. 20).

A cultura é tecida dessa simbiose entre mediação e interação. As espacialidades informacionais, ou por onde circulam e se compartilham as informações, são híbridas. 0 mundo contemporâneo da informação, ou da chamada "cultura informacional", opera nas interfaces relacionais entre o global e o local, promovendo e realçando o que Canclini (2003) chama de "glocal". Nessa simbiose do espaço entre também se situam a comunicação e a informação.

\begin{abstract}
Situadas nos glocais, mas jamais estáveis ou definidas, essas novas espacialidades interativas do mediar estabelecem a distância entre mediações e interações, assumindo, mais que nunca, extraordinária importância política, mas diferindo fundamentalmente dos anteriores dispositivos do controle mediativo. (FERRARA, 2015, p. 22).
\end{abstract}

Ainda que as questões sobre os conceitos difusos de globalização (opção mais usada pelos americanos) e de mundialização (opção mais usada pelos franceses) apontem para imprecisões teóricas sobre os fenômenos informacionais e comunicacionais contemporâneos, e da visada teórica de Néstor Garcia Canclini (2003) sobre os hibridismos que se sucedem dessas trocas simbólicas entre o local o global e o aparecimento do que ele chama de glocal, o certo é que já não cabem mais imprecisões epistemológicas sobre o conceito de mediação e suas interfaces com a interação, mormente quando usados pela Ciência da Informação.

Na globalização, a cultura é desterritorializada na sua produção e recepção, as expressões culturais são retiradas de seu contexto original e reapropriadas de maneira diferente em cada lugar; os significados da cultura são disseminados de forma desigual, ao mesmo tempo em que as apropriações são altamente contextuais. (MARTINO, 2010, p. 45).

Essa reflexão é importante para aclarar os posicionamentos que este texto vem tratando para esclarecer algumas questões sobre os conceitos de mediação da informação e seus usos pela Ciência da Informação. 0 espaço local que define os atributos de uma "boa mediação" informacional, bem como os discursos que asseveram condicionamento para a chamada "competência informacional", conforme determinado pelas "mediações programadas", precisam levar em conta que os espaços culturais para onde se voltam as informações, seus fluxos e suas demandas também se apresentam difusos quanto aos aspectos culturais e identitários das demandas por informações. 
Há nessa nova espacialidade cultural hibridismos culturais e identitários que alteram substancialmente o papel sociocultural da informação, que deve definir mais claramente de que tipo de mediação estamos falando. Da mesma forma, as práticas das comunidades contempladas pela mediação informacional são plurais, desterritorializadas e diversas. Já não são mais as fronteiras nacionais ou comunitárias que definem demandas informacionais, mas o que advém das frestas presentes nas fronteiras, do que pode advir das porosidades culturais e identitárias. Ainda que muitos autores chamem de culturas ou identidades globais, o que está em jogo são contaminações diversas, diferenças culturais que se aglutinam na mesma espacialidade global e a incessante reapropriação simbólica pelo local. Dito de outra forma, os estudos sobre mediação não podem prescindir do entendimento de que eles devem ser geridos e negociados a partir de entendimentos que aconteçam também nas porosidades do entre mediar e interagir, onde se dão as trocas híbridas e as simbologias das demandas globais, locais e glocais. Para Luís Mauro Sá Martino (2010, p. 46),

\footnotetext{
[...] a identidade é construída a partir da intersecção do fluxo global de imagens, em um movimento híbrido de apropriação de significados, articulação de ideias e modos de agir; o local e o global se articulam no nível individual/grupal da apropriação particular de práticas e valores.
}

Assim, retomando a noção de "apropriação da informação" contida na ementa da disciplina "Cultura e Mediação da Informação", devemos lançar mão de estudos antropológicos tanto da cultura como da informação para garantir que a noção dessa apropriação não erre também por contemplar apenas aquela já mencionada noção de mediação unilateral e linear de um emissor/produtor para um emissor. Pensar numa mediação que potencialize uma apropriação da informação de fato, implica entender o cenário glocal e híbrido no qual essa apropriação se dará, o que será decisivo para aferir a quantas andam os processos de mediação informacional. Se eles estão focando na produção e disseminação de informação apenas ou se existe preocupação em levar em conta os processos de reação do usuário da informação na relação complexa e híbrida com seus pares, com as identidades culturais múltiplas para onde será reverberada a informação apropriada.

\section{CONSIDERAÇÕES FINAIS}

Os estudos sobre mediação dão conta da complexidade de sua abrangência e das ações que uma mediação potencializa. Não à toa, é um conceito que se encontra em campos vários do saber. Associado à mediação sociocultural da informação, ela não acontece apenas 
circunscrita aos mecanismos e estratégias de organização e disseminação da informação. Qualquer mediação informacional precisa se prolongar incerta e complexamente nas possibilidades de reações que essa informação propagada provoca nos contextos reclamados por suas demandas. Da mesma forma, o feedback dessa propagação como elemento avaliador e mediador dos sistemas e serviços de informação.

No âmbito das premissas teóricas, conceituais e metodológicas aprisionadas em quaisquer ementas, a disciplina precisa se desprender do disciplinamento e experimentar a transdisciplinaridade como voo libertador, promotor de uma ponte imaginária que, mais do que ligar dois pontos, precisa uni-los na tarefa lúcida e inadiável de conhecer sob os auspícios das muitas vozes científicas que, mesmo diferentes, possibilitam o entendimento do complexo.

Assim, uma mediação sociocultural da informação implica levar as pesquisas de mediação no âmbito da Ciência da Informação para as leituras antropológicas das culturas e das informações que produzem, fazem circular e são recebidas, conhecendo-se todos os contextos desse transitar, desse interagir, desse mediar.

Não pode o conceito de mediação ficar ao sabor do discurso ou refém de um não esclarecimento. Dizer que há mediação implica prová-la à luz de uma epistemologia que ultrapasse a dicotomia dar/receber, inaugurada e mantida sem atualizações teóricas à luz do conceito matemático de comunicação, que liga - muitas vezes sem unir - emissor com receptor.

Para além dos discursos sobre a importância das mediações culturais e informacionais, é necessário entender essa mediação contemplando as formas contemporâneas de interação, de interacionismo simbólico, de cumplicidades culturais, de trocas simbólicas e de como esses fenômenos modificam os contextos de onde são produzidas as informações, mas também aqueles por onde elas circulam e nos quais são recebidas para provocarem, aí sim, as verdadeiras mediações socioculturais.

Assim, a prática bibliotecária, mesmo a de maior facilidade de aferição junto aos seus usuários, precisa remodelar o conceito de mediação à luz dos processos culturais advindos das reações dos sujeitos e das culturas destes, e não apenas aferindo seus modos de organização e tratamento da informação.

Alguns estudos da área da Ciência da Informação já ventilam as teorias com essa visada de mediação mais complexa, como vimos. Há conceitos de mediação que ora se aproximam, ora se afastam do fazer pragmático em bibliotecas ou unidades de informação. Nos demais 
espaços por onde a informação circula e cujas mediações são demandadas, os estudos sobre mediação ainda precisam chegar com a ajuda dos estudos transdisciplinares sobre o tema mediação.

Se o objeto da Ciência da Informação é a mediação da informação, e não a informação em si, é explicável a preocupação levantada acerca da necessidade dessa mediação ser estudada nos contextos culturais por onde circula, de onde é demandada e os contextos de atendimento a essas demandas. Em outras palavras e a fim de elucidar as fronteiras das disciplinas; dos perigos dos seus disciplinamentos; de quaisquer possibilidades de desengaiolar epistemologias e ementários, e fazer com que as ementas apenas apontem possibilidades de voos transdisciplinares, convém ao mediador de disciplinas sugeridas a estudos pós-graduados levar essas questões consigo e não se esquecer do que disse Paulo Freire a este pesquisador numa de suas aulas de pós-graduação em Comunicação e Semiótica, na PUC-SP, no ano de 1993: "Nos casos de engessamento de disciplinas pelas suas ementas, pense que elas não importam. O que importa é quem vai mediar a disciplina". Uma tarefa a mais para os professores mediadores.

\section{REFERÊNCIAS}

ALMEIDA JÚNIOR, Oswaldo Francisco de. Mediação da Informação e múltiplas linguagens. Pesquisa brasileira em Ciência da Informação, Brasília, v. 2, n. 1, p. 89-103, jan./dez. 2009.

BELLUZZO, Regina Célia Baptista; FERES, Glória Georges. Competência em informação, redes de conhecimento e as metas educativas para 2021: reflexões e inter-relações. In: Redes de conhecimento e competência em informação: mediação e uso da informação. Rio de Janeiro: Interciência, 2015. p. 1-36.

CANCLINI, Nestor Garcia. Culturas híbridas: estratégias para entrar e sair da modernidade. 4. ed. São Paulo: EDUSP, 2003.

CAUNE, Jean. Cultura e comunicação: convergências teóricas e lugares de mediação. São Paulo: UNESP, 2014.

CAVALCANTE, Lídia Eugênia. Diálogos entre informação social, mediação cultural e comunidade. In: BELLUZZO, Regina Célia Baptista; FERES, Glória Georges; VALENTIM, Marta Lígia Pomim (Org.). Redes de conhecimento e competência em informação: mediação e uso da informação. Rio de Janeiro: Interciência, 2015. p. 399-412.

CERTEAU, Michel de. A invenção do cotidiano. Petrópolis: Vozes, 1994.

D’AMBRÓSIO, Ubiratan. Transdisciplinaridade. São Paulo: Palas Atena, 1997. 
ELIAS, Norbert. 0 processo civilizador: uma história dos costumes. Rio de Janeiro: Zahar, 1990.

FERRARA, Lucrécia D’Aléssio. Comunicação, mediações, interações. São Paulo: Paullus, 2015.

FREIRE, Paulo. Ação cultural para a liberdade e outros escritos. 14. ed. São Paulo: Paz e Terra, 2011.

FROHMAN, B. O caráter social, material e público da informação. In: FUJITA, M.; MARTELETO, R.; LARA, M. (Org.). A dimensão epistemológica da ciência da informação e suas interfaces técnicas, políticas e institucionais nos processos de produção, acesso e disseminação da informação. São Paulo: Cultura Acadêmica; Marília: Fundepe, 2008. p. 1934 .

GEERTZ, Clifford. A interpretação das culturas. Rio de Janeiro: LTC, 1989.

LARAIA, Roque de Barros. Cultura: um conceito antropológico. 26 reimp. Rio de Janeiro: Zahar, 2008.

MALHEIRO, Armando; RIBEIRO, Fernanda. Paradigmas, serviços e mediações em Ciência da Informação. Recife: Néctar, 2011.

MARTIN-BARBERO, Jésus. Dos meios às mediações. 6. ed. Rio de Janeiro: UFRJ, 2009.

MARTINAZZO, Celso José. A utopia de Edgar Morin: da complexidade à concidadania planetária. 2. ed. Ijuí: Unijuí, 2004.

MARTINO, Luis Mauro Sá. Comunicação e identidade: quem você pensa que é? São Paulo: Paullus, 2010.

Comunicação: troca cultural? São Paulo: Paullus, 2005.

MORAES, Maria Cândida. Transdisciplinaridade, criatividade e educação: fundamentos ontológicos e epistemológicos. Campinas: Papirus, 2015.

MORIN, Edgar. Epistemologia da complexidade. In: SCHNITMAN, D. F. (Org.). Novos paradigmas, cultura e subjetividade. Porto Alegre: Artes Médicas, 1996. p. 45-55.

Introdução ao pensamento complexo. 3. ed. Porto Alegre: Sulina, 2007.

PEIRCE, Charles Sanders. Escritos coligidos. 2. ed. São Paulo: Abril Cultural, 1980. (Os Pensadores)

RODRIGUES, Adriano Duarte. Comunicação e cultura: a experiência cultural na era da informação. Lisboa: Editorial Presença, 1994.

SANTOS NETO, João Arlindo dos; ALMEIDA JÚNIOR, Oswaldo Francisco de. A competência em informação e o bibliotecário mediador da informação na biblioteca universitária. In: BELLUZZO, Regina Célia Baptista; FERES, Glória Georges; VALENTIM, Marta Lígia Pomim 
116 | Feitosa | Complexas mediações

(Org.). Redes de conhecimento e competência em informação: mediação e uso da informação. Rio de Janeiro: Interciência, 2015. p. 359-376.

THOMPSON, John B. A mídia e a modernidade: uma teoria social da mídia. 2. ed. Petrópolis: Vozes, 1999. 


\section{SOBRE O AUTOR}

\section{Luiz Tadeu Feitosa}

Professor do Departamento de Ciências da Informação e do Programa de Pós-Graduação em Ciência da Informação da Universidade Federal do Ceará.

E-mail: tadeu.feitosa62@gmail.com

Recebido em: 07/06/2016; Revisado em: 08/06/2016; Aceito em: 20/06/2016.

\section{Como citar este artigo}

FEITOSA, Luiz Tadeu. Complexas mediações: transdisciplinaridade e incertezas nas recepções informacionais. Informação em Pauta, Fortaleza, v. 1, n. 1, p. 98-117, jan./jun. 2016. 